Sains Malaysiana 50(1)(2021): 239-251

http://dx.doi.org/10.17576/jsm-2021-5001-23

\title{
Effect of Sulfur on Nitrogen-Containing Plasma Polymers in Promoting Osteogenic Differentiation of Wharton's Jelly Mesenchymal Stem Cells
}

(Kesan Sulfur ke atas Polimer Plasma yang Mengandungi Nitrogen dalam Mempromosi Pembezaan Osteogen Sel Stem Mesenkima Jeli Wharton)

\author{
Kim Shyong Siow*, Arifah Rahman, Amnani Aminuddin \& Pei Yuen NG
}

\begin{abstract}
The role of sulfur and its synergistic effects with nitrogen moieties in mediating stem cell proliferation and differentiation has become of interest to the tissue engineering community due to chemical similarities with the glycosaminoglycans found in human tissues and cells. Glycosaminoglycans are biomolecules known to influence stem cell differentiation, but the roles of sulfur with different oxidation states on nitrogen-containing polymers have not been fully understood nor investigated. In this study, we used the plasma polymerization of 1,7-octadiene (ppOD), n-heptylamine (ppHA), ppHA grafted with vinyl-sulfonate via Michael-type addition (ppHA-SO $)$, thiophene (ppT), and $p p T$ with air plasma treatment (ppT-air) to produce controlled amounts of nitrogen and sulfur moieties having different oxidation states, as confirmed by x-ray photoelectron spectroscopy. Assays of the proliferation and osteogenic activities of Wharton's jelly mesenchymal stem cells (WJ-MSCs) showed the highest activities for ppHA, followed by ppHA-SO, due to high percentages of amines/amides and the absence of $\mathrm{SO}_{3}$ moieties in $\mathrm{ppHA}$. Other plasma polymers showed less proliferation and osteogenic differentiation than the positive control (glass substrate); however, WJ-MSCs grown on ppT-air with its high percentages of $\mathrm{SO}_{4}$ displayed cytoskeletons intensified with actin stress fiber, unlike the thiol-dominated ppT. Finally, the presence of methyl groups in ppOD severely limited WJ-MSCs proliferation and differentiation. Overall, these results confirm the beneficial effects of amine/amide groups on WJ-MSCs proliferation and osteogenic differentiation, but the combination of these groups with sulfur of various oxidation states failed to further enhance such cellular activities.
\end{abstract}

Keywords: Amine-amide; osteogenic differentiation; plasma polymerization; plasma treatment; sulfonate-sulfate

\section{ABSTRAK}

Peranan sulfur dan kesan sinerginya dengan molekul nitrogen dalam pertumbuhan dan pembezaan sel stem telah mendapat perhatian komuniti kejuruteraan tisu kerana persamaan kimianya dengan glikosaminoglikan yang terdapat di dalam tisu dan sel manusia. Glikosaminoglikan dikenali sebagai biomolekul yang dapat mempengaruhi pembezaan sel stem. Walau bagaimanapun, peranan sulfur yang mempunyai tahap pengoksidaan yang berbeza di dalam polimer yang mengandungi nitrogen masih kurang difahami. Justeru, kajian ini menggunakan pempolimeran plasma 1,7-oktadiena (ppOD), n-heptilamina (ppHA), ppHA yang dicantum dengan vinil-sulfonat melalui penambahan Michael (ppHA-SO $)$, tiofena ( $p p T)$ dan ppT dengan rawatan plasma udara (ppT-udara) untuk menghasilkan moieti nitrogen dan sulfur yang mempunyai keadaan pengoksidaan yang berbeza yang dikenal pasti dengan spektroskopi fotoelektron x-ray. ppHA menunjukkan aktiviti pertumbuhan dan pembahagian osteogen sel stem mesenkima jeli Wharton (WJ-MSC) yang paling tinggi diikuti oleh ppHA-SO ${ }_{3}$. Keputusan ini berpunca daripada kandungan peratusan amina/amida yang tinggi dan ketiadaan moieti $\mathrm{SO}_{3}$ dalam salutan ppHA. Manakala, polimer plasma lain menunjukkan aktiviti pertumbuhan dan pembahagian osteogen WJ-MSC yang rendah berbanding dengan kawalan positif (substrat kaca). Walau bagaimanapun, ppT-udara yang mengandungi peratusan $\mathrm{SO}_{4}$ yang tinggi menunjukkan pertumbuhan WJ-MSC dengan sitoskeletonnya diperkuat dengan gentian tegangan aktin berbanding dengan ppT yang mempunyai kandungan tiol yang tinggi. Selain itu, ppOD menunjukkan pengurangan yang ketara dalam aktiviti pertumbuhan dan pembahagian osteogen WJ-MSC disebabkan oleh kehadiran kumpulan metil. Secara keseluruhannya, kajian ini membuktikan bahawa kumpulan amina/amida mampu memberi kesan yang positif dalam pertumbuhan dan pembahagian osteogen WJ-MSC. Namun demikian, kombinasi kumpulan amina/amida dengan sulfur yang mengandungi pelbagai keadaan pengoksidaan gagal untuk meningkatkan akitiviti sel.

Kata kunci: Amina-amida; pembahagian osteogen; pempolimeran plasma; rawatan plasma; sulfonat-sulfat 


\section{INTRODUCTION}

Sulfur (S) and nitrogen (N) containing chemical groups are important parts of biological molecules and interfaces in human tissues and cells. Among these are glycosaminoglycans, such as heparan sulfate, chondroitin sulfate, and dermatan sulfate, which have been identified to mediate the differentiation of mesenchymal stem cells (MSCs) (Manton et al. 2007; Uygun et al. 2009). Additional individual chemical moieties have been investigated for roles in mediating MSCs attachment and proliferation (Curran et al. 2006; Liu et al. 2014), including aldehyde (Sandstrom et al. 2013), methyl $\left(\mathrm{CH}_{3}\right)$, amine $\left(\mathrm{NH}_{2}\right)$, carboxyl (COOH) (Wells et al. 2009), silane $\left(\mathrm{SiH}_{4}\right)$, thiol (SH) (Liu et al. 2013) and hydroxyl (OH) (Keshel et al. 2011) groups.

Except for those from the hematopoietic system, stem cells are anchorage-dependent and require substrate attachment before differentiation can proceed. Chemical modification of a substrate can influence protein adsorption, which affects the subsequent cell attachment. In particular, hydrophobic surfaces such as those modified with $\mathrm{CH}_{3}$ have been shown to not support stem cell adhesion on account of preferential albumin adsorption, which prevents cell attachment. Meanwhile, hydrophilic surfaces with chemical groups like $\mathrm{NH}_{2}, \mathrm{OH}$, and $\mathrm{COOH}$ adsorb proteins (i.e. fibronectin) that promote cell attachment; these affect the cells' focal contact formation and resulting cellular morphology (Mager et al. 2011).

In these MSCs studies, the primary methods for controlling the density of chemical moieties were plasma modifications (Curran et al. 2013; Keshel et al. 2011; Liu et al. 2014, 2015) and self-assembled monolayers (SAM) (Keselowsky et al. 2003; Phillips et al. 2010; Scotchford et al. 2002). The SAM approach requires a specific substrate, such as a gold surface for alkanethiols; meanwhile, plasma modification has proven to be a versatile technique capable of controlling the density of chemical moieties on different substrates with ease, particularly in the case of the co-polymerization approach (Liu et al. 2015; Siow et al. 2017). In addition, plasma modification produces a sterile surface upon completion; this reduces processing steps and renders the operation scalable and economically viable.

While we were initially motivated by interest in the roles of glycosaminoglycans in MSCs differentiation, we limited the scope of this current research to certain S-related and N-related species found in glycosaminoglycans. Such an approach is not uncommon, and in fact is demonstrated by the majority of research in this area, which analysed the moieties summarized earlier. Literature search has also identified the positive role of $\mathrm{NH}_{2}$ in promoting osteogenesis, and here, we focused on the addition of $\mathrm{S}$ containing chemical groups on these $\mathrm{N}$ containing chemical groups found on plasma polymers and their biological responses.

Our plasma-based approach applied two methods to produce $\mathrm{S}$ groups of different oxidation states: firstly, plasma polymerization of thiophene ( $\mathrm{ppT}$ ) followed by air plasma treatment of the thiophene plasma polymers (ppT-air) (Akhavan et al. 2014; Siow et al. 2020), and secondly, grafting of vinyl sulfonate moieties onto n-heptylamine plasma polymers via the Michael-type addition route ( $\mathrm{ppHA}-\mathrm{SO}_{3}$ ) (Siow et al. 2019). In order to study the influence of these chemical moieties, we perform initial screening in the form of a stem cell attachment study (i.e. cell viability), followed by a more detailed osteogenic differentiation study (i.e. gene expression analysis, alkaline phosphatase activity, and alizarin red $\mathrm{S}$ staining) to provide a more accurate reflection of the plasma-modified substrates.

\section{MATERIALS AND METHODS}

\section{MATERIALS}

Vinyl-sulfonic acid sodium salt solution $\left(25 \%\right.$ in $\mathrm{H}_{2} \mathrm{O}$, product no: 278416 ), thiophene ( $>99 \%$, product no: T31801), 1,7-octadiene (98\%, product no: 02501), and heptylamine (99\%, product no: 126802) were procured from Sigma-Aldrich (USA). HEPES (product no: 15630080), RapidOut DNA removal kits (product no: K2981), and staining solutions of Alexa Fluor 488 phalloidin and DAPI (product no: 62248) were purchased from Thermo Fisher Scientific (USA).

\section{SUBSTRATE PREPARATION}

Silicon wafers were used as substrates throughout this study; these had a thickness of $500 \pm 25 \mu \mathrm{m}$, orientation of $100 \pm 0.5^{\circ}$, resistivity of $1-10 \mathrm{ohm} . \mathrm{cm}$, and were polished on one side. These silicon substrates were cut into $1 \mathrm{~cm}^{2}$ pieces before being sequentially ultrasonically cleaned in isopropyl alcohol, acetone, and Mili-Q water.

\section{SURFACE PLASMA POLYMERIZATION AND TREATMENT}

A radio frequency generator (Model: RFMN-150) with a frequency of $13.56 \mathrm{MHz}$ was connected to a custombuilt plasma reactor as described previously (Siow et al. 2014). Firstly, the plasma reactor was pumped down to a base pressure of $1.5 \mathrm{~Pa}$ and an air-plasma treatment (25 Pa, $10 \mathrm{~W}, 1 \mathrm{~min}$ ) was performed to clean the silicon substrate. Then, thiophene (T), heptylamine (HA), or 1,7-octadiene (OD) monomers were fed into the reactor for plasma polymerization using a needle valve controlled by a stinger gauge; the resultant plasma polymers are henceforth labelled as ppT, ppHA, and ppOD, respectively. The monomers were used without further purification, 
and the optimized deposition parameters were as follows: ppT: $25 \mathrm{~Pa}, 15 \mathrm{~W}$, and 2 min; ppHA: $25 \mathrm{~Pa}, 10 \mathrm{~W}$, and 90 $\mathrm{s}$; and ppOD: $25 \mathrm{~Pa}, 10 \mathrm{~W}$, and $10 \mathrm{~min}$. The ppHA coating was grafted with the vinyl- $\mathrm{SO}_{3}$ group ( $\mathrm{ppHA}-\mathrm{SO}_{3}$ ) via Michael-type addition by dipping into a vinyl-sulfonic acid sodium salt solution for $10 \mathrm{~min}$ (Siow et al. 2019). The ppT coating was further air plasma-treated to oxidize the thiophene plasma polymers (ppT-air) with the following parameters: $25 \mathrm{~Pa}, 13 \mathrm{~W}$, and $2 \mathrm{~min}$ (Akhavan et al. 2014).

\section{SURFACE CHEMICAL STUDY: X-RAY PHOTOELECTRON SPECTROSCOPY ANALYSIS}

The chemical compositions and oxidation states of the plasma polymers were identified with an X-ray photoelectron spectrometer (ULVAC-PHI Quantera II) consisting of a monochromatic Al-K $\alpha$ source $(\mathrm{hv}=1486.6$ $\mathrm{eV}$ ) operated at settings of $25 \mathrm{~W}, 15 \mathrm{kV}$. The elemental percentages of the plasma polymers coatings were calculated from their survey spectra with the SmartsoftXPS 3.5.1.1. Error analysis of the $\mathrm{O} / \mathrm{C}, \mathrm{N} / \mathrm{C}$, and $\mathrm{S} / \mathrm{C}$ ratios was carried out as described elsewhere (Siow et al. 2017).

The high-resolution spectra were component-fitted with Casa-XPS (version 2.3.16) using the following settings: Shirley background subtraction, full-width half maximums in the range of 1.46 and $1.55 \mathrm{eV}$, and Gaussian-Lorentzian shape with a $30 \%$ Lorentzian component. To offset the surface charging effect, all binding energies were calibrated to the neutral $\mathrm{C}-\mathrm{C}$ and $\mathrm{C}-\mathrm{H}$ component at $285.0 \mathrm{eV}$. Reference binding energies for C-O and C-N were grouped between 286.1 and 286.4 $\mathrm{eV}$ to account for slight chemical shifts in different samples, an approach that has been adopted elsewhere (Chan et al. 2016; Liu et al. 2014). The oxidation states of $\mathrm{N}$ and $\mathrm{S}$ and their binding energies were reported elsewhere (Chen et al. 2016; Siow et al. 2018). The binding energies of $\mathrm{SO}$ and $\mathrm{SO}_{2}$ were grouped due to being proximate (Akhavan et al. 2014; Siow et al. 2018); the ratio of $S 2 p_{1 / 2}$ and $\mathrm{S} 2 \mathrm{p}_{3 / 2}$ areas was also set at 1:2 separated by $1.2 \mathrm{eV}$ in binding energy (Beamson \& Briggs 1992).

\section{STEM CELL ADHERENCE AND VIABILITY ASSAY}

Wharton's jelly-derived mesenchymal stem cells (WJMSCs) at passage two were obtained from a single patient donor of the Tissue Engineering Centre, Universiti Kebangsaan Malaysia. Passages three to five were used for subsequent studies. The plasma polymers coatings (ppOD, ppHA, ppHA-SO, ppT, ppT-air) were sterilized by ultra-violet irradiation before being utilized in cell viability assays. WJ-MSCs were seeded at a density of $2 \times 10^{4}$ cells $/ \mathrm{cm}^{2}$ on the sterilized plasma polymers coatings and a glass coverslip (positive control), and all were incubated at $37{ }^{\circ} \mathrm{C}$ in growth media for designated timeframes (i.e. 7, 14, and 21 days). The growth of WJ-MSCs on the samples was determined by 3-(4,5-dimethylthiazol2-yl)-2,5 diphenyltetrazolium bromide (MTT) assay. At the end of the incubation, the MTT dye was aspirated off and dimethyl sulfoxide was added to dissolve insoluble MTT-formazan crystals. Finally, the optical absorbance of samples was measured at a wavelength of $570 \mathrm{~nm}$ using a microplate reader (Infinite M200PRO, Tecan Life Sciences, Switzerland). All experiments were carried out in triplicate. Results are presented in terms of cell viability as calculated using (1):

Cell viability $(\%)==\frac{\text { optical absorbance of treated substrate }}{\text { Optical absorbance of control }} \times 100 \%$

\section{CYTOSKELETON STAINING}

For cytoskeleton staining, WJ-MSCs were seeded at a density of $2 \times 10^{4}$ cells $/ \mathrm{cm}^{2}$ on the various plasma polymers coatings and a glass coverslip (positive control). The seeded samples were incubated for 7,14 , and 21 days in a humidified atmosphere with $5 \% \mathrm{CO}_{2}$ and at a temperature of $37{ }^{\circ} \mathrm{C}$. Afterwards, samples were stained using Alexa Fluor 488 phalloidin and DAPI, cleaned with PBS solution (twice), and finally analysed under a fluorescence microscope (Model: BX51 Olympus, Japan) in multi-track mode; fluorescein phalloidin emission was determined with excitation wavelength at $495 \mathrm{~nm}$ and emission wavelength at $518 \mathrm{~nm}$, whereas blue DAPI was observed at an excitation wavelength of $341 \mathrm{~nm}$ and emission wavelength of $452 \mathrm{~nm}$.

\section{OSTEOGENIC GENE EXPRESSION (REAL-TIME POLYMERASE CHAIN REACTION (QPCR))}

WJ-MSCs were seeded at a density of $1 \times 10^{5}$ cells/well on a six-well plate containing each plasma polymers coating, and cell attachment was allowed to proceed overnight. Osteogenic differentiation was then induced by treatment with osteogenic medium (i.e. the growth medium plus an additional $1 \%$ ascorbic acid, $100 \mathrm{nM}$ dexamethasone, and $10 \mathrm{mM}$ beta-glycerol phosphate) for 21 days with a change of media every three days. The negative control group used in this assay consisted of undifferentiated WJ-MSCs (i.e. cells grown in basal growth media without the osteogenic-promoting additives). The three-step thermal cycling protocol for cDNA synthesis consisted of an initial denaturation step of $95^{\circ} \mathrm{C}$ for $2 \mathrm{~min}$ followed by 40 cycles of $95^{\circ} \mathrm{C}$ for $5 \mathrm{~s}, 60^{\circ} \mathrm{C}$ for $10 \mathrm{~s}$, and $72^{\circ} \mathrm{C}$ for $20 \mathrm{~s}$. After synthesis, melt-curve analysis was performed to evaluate the reaction specificity. Expression levels of the osteogenic genes Runt-related transcription factor 2 (RUNX2) and osteopontin (OPN) were normalised to a reference gene, $\beta$-actin. qPCR was performed with notemplate and no-reverse transcriptase quality controls. 
OSTEOGENIC CELL STAINING (ALIZARIN RED S)

WJ-MSCs were cultured in osteogenic media for 7, 14, and 21 days and then washed with PBS (twice) before being fixed with $4 \%$ (v/v) formaldehyde for $30 \mathrm{~min}$. Fixed cells were then carefully aspirated and washed with distilled water (thrice). Afterwards, the cells were stained with $1 \%$ alizarin red S and incubated at room temperature for 60 min. Then, the samples were washed with distilled water to remove any excess stain, and finally imaged with an inverted microscope (Model: BX51, Olympus, Japan).

\section{OSTEOGENIC CELL ACTIVITY (ALKALINE PHOSPHATASE} ASSAY)

Alkaline phosphatase (ALP) activity was measured by the hydrolysis of p-nitrophenyl phosphate disodium hexahydrate (pNPP). In brief, WJ-MSCs were grown on different plasma polymers coatings at a density of $2 \times 10^{4}$ cells $/ \mathrm{cm}^{2}$ in osteogenic media for 7, 14, and 21 days. After incubation, the cells were lysed with Triton X-100 (0.1\% in PBS). Then, $50 \mu \mathrm{L}$ of test sample was combined with $100 \mu \mathrm{L}$ of pNPP ( $5 \mathrm{mM}$ ) followed by $50 \mu \mathrm{L}$ of 2 -amino-2methyl-1 propanol buffer, after which pNPP hydrolysis was immediately stopped by the addition of $1.0 \mathrm{M} \mathrm{NaOH}$ $(20 \mu \mathrm{L})$. The optical absorbance of the samples was measured using an inverted microscope (Model: BX51, Olympus, Japan).

\section{STATISTICAL ANALYSIS}

One-way analysis of variance was performed using OriginPro 8 , and $p$ values of less than 0.05 were regarded as statistically significant. All experiments were repeated in triplicate across three different cycles of the plasma polymerization process.

\section{RESULTS AND DISCUSSION}

\section{X-RAY PHOTOELECTRON SPECTROSCOPY ANALYSIS}

Surface chemical composition is one of the most critical factors for controlling stem cell attachment, proliferation, and differentiation. X-ray photoelectron spectroscopy was selected as the surface analysis tool for these plasma polymers because of the rich information it provides, specifically elemental and oxidation states for the top $10 \mathrm{~nm}$ of a coating. Aside from the $\mathrm{HA}-\mathrm{SO}_{3}$ plasma polymers, $\mathrm{X}$-ray photoelectron spectroscopy analyses of these coatings have been published elsewhere (Siow et al. 2020), and are reproduced here in Table 1 for readers' convenience and with further analysis $(\mathrm{O} / \mathrm{C}, \mathrm{N} / \mathrm{C}$, and S/C), while their component-fitted spectra are included in the Supplementary Information.

TABLE 1. Representative $\mathrm{x}$-ray photoelectron spectroscopy

survey scan results for plasma-modified substrates

\begin{tabular}{lccccccc}
\hline & \multicolumn{3}{c}{ Atomic concentration $\%$} & \multicolumn{3}{c}{ Atomic ratio } \\
\hline \multicolumn{1}{c}{ Sample } & $\% \mathrm{C}$ & $\% \mathrm{~N}$ & $\% \mathrm{O}$ & $\% \mathrm{~S}$ & $\mathrm{O} / \mathrm{C}$ & $\mathrm{N} / \mathrm{C}$ & $\mathrm{S} / \mathrm{C}$ \\
\hline ppOD & 92.0 & 0.9 & 7.1 & - & $0.08 \pm 0.01$ & $0.01 \pm 0.00$ & - \\
ppHA & 81.8 & 10.0 & 8.2 & - & $0.10 \pm 0.01$ & $0.12 \pm 0.01$ & - \\
ppHA-SO $_{3}$ & 82.1 & 8.5 & 8.7 & 0.7 & $0.11 \pm 0.01$ & $0.10 \pm 0.01$ & $0.01 \pm 0.00$ \\
ppT & 75.1 & - & 4.6 & 20.3 & $0.06 \pm 0.01$ & - & $0.27 \pm 0.02$ \\
ppT-air & 53.2 & 7.0 & 23.0 & 16.8 & $0.43 \pm 0.02$ & $0.13 \pm 0.01$ & $0.31 \pm 0.01$ \\
\hline
\end{tabular}

In the case of ppHA grafted with vinyl- $\mathrm{SO}_{3}$ via Michael-type addition, the low percentage of S (circa 1 at $\%$ ) suggests a monolayer thickness of grafted S-moieties; the component-fitting of the S2p peak confirmed that these moieties remain in the $\mathrm{SO}_{3}$ oxidation state (Silver et al. 1999; Siow et al. 2019). The Michael-type addition step for $\mathrm{ppHA}-\mathrm{SO}_{3}$ did not significantly increase the $\mathrm{O} / \mathrm{C}$ ratio because the grafting layer of vinyl- $\mathrm{SO}_{3}$ was much thinner than the X-Ray Photoelectron Spectroscopy probing depth of approximately $10 \mathrm{~nm}$. However, post-plasma oxidation did result in a slight increase of moieties associated with $\mathrm{C}-\mathrm{O}$ and $\mathrm{C}=\mathrm{O}$, as illustrated by the component-fitting of $\mathrm{C} 1 \mathrm{~s}$ spectra for $\mathrm{HA}-\mathrm{SO}_{3}$ (Table 2). 
TABLE 2. Component-fitted C1s, S2p, and N1s spectra for representative coatings in terms of atomic \% based on published binding energies (Chen et al. 2016; Siow et al. 2018, 2020; Beck et al. 2005; Supplementary S1)

\begin{tabular}{|c|c|c|c|c|c|c|}
\hline \multirow[b]{2}{*}{ Components (at $\%$ ) } & \multirow[b]{2}{*}{$\begin{array}{c}\text { Binding energy } \\
(\mathrm{eV})\end{array}$} & \multirow[b]{2}{*}{ ppOD } & \multicolumn{4}{|c|}{ Type of Monomer } \\
\hline & & & ppHA & ppHA-SO & $\mathrm{ppT}$ & ppT-air \\
\hline \multicolumn{7}{|l|}{$\underline{\mathrm{C} 1 \mathrm{~s}}$} \\
\hline $\mathrm{C}-\mathrm{C}, \mathrm{C}-\mathrm{H}$ & 285.0 & 58.9 & 67.9 & 62.1 & 56.8 & 32.2 \\
\hline $\mathrm{C}-\mathrm{N}, \mathrm{C}-\mathrm{O}-\mathrm{C}$ & $286.1-286.4$ & 25.8 & 10.8 & 16.3 & 14.9 & 15.0 \\
\hline $\mathrm{C}=\mathrm{O}, \mathrm{N}-\mathrm{C}=\mathrm{O}$ & $287.6-288.0$ & 7.3 & 3.1 & 3.7 & 3.4 & 4.0 \\
\hline $\mathrm{O}-\mathrm{C}=\mathrm{O}$ & 289.0 & 0 & 0 & 0 & 0 & 2.0 \\
\hline \multicolumn{7}{|l|}{$\underline{S 2 p}$} \\
\hline S-C, S-H, S-S & $163.6-164.0$ & 0 & 0 & 0 & 20.3 & 12.5 \\
\hline $\mathrm{S}=\mathrm{O}, \mathrm{SO}_{2}$ & $165.7-167.0$ & 0 & 0 & 0 & 0 & 0.7 \\
\hline $\mathrm{SO}_{3}$ & $168.2-168.4$ & 0 & 0 & 0.7 & 0 & 0 \\
\hline $\mathrm{SO}_{4}$ & 168.8 & 0 & 0 & 0 & 0 & 3.6 \\
\hline \multicolumn{7}{|l|}{ N1s } \\
\hline C-N (Amine) & $398.9-399.1$ & 0.9 & 8.3 & 3.0 & 0 & 3.1 \\
\hline $\mathrm{N}-\mathrm{C}=\mathrm{O}$ (Amide) & $400.1-400.2$ & 0 & 1.7 & 4.5 & 0 & 1.0 \\
\hline $\begin{array}{l}\mathrm{NH}^{+} \text {(Protonated } \\
\text { Amine) }\end{array}$ & $401.0-401.2$ & 0 & 0 & 1.0 & 0 & 2.9 \\
\hline
\end{tabular}

Concerning S2p in the context of ppT and ppT-air, the emergence of oxidised $\mathrm{S}$ was consistent with the increase of $\mathrm{O} / \mathrm{C}$ ratio from 0.06 (ppT) to 0.43 (ppT-air). It is also likely that this oxidized $\mathrm{S}$ was $\mathrm{SO}_{4}$, not $\mathrm{SO}_{3}$ because of the increase in binding energy of the curvefitted component. The exact molecular arrangement of $\mathrm{SO}_{4}$ within the cross-linked plasma polymer remains to be seen because the insertion of $\mathrm{O}$ between $\mathrm{SO}_{3}$ and $\mathrm{C}$ or another $\mathrm{S}$ in the ppT may be prohibitive. At the same time, the $\mathrm{N} / \mathrm{C}$ ratio also increased to 0.13 , which could be attributed to plasma treatment with $\mathrm{N}_{2}$ from the atmosphere
(Akhavan et al. 2014). Compared to ppT, the componentfitted $\mathrm{C} 1 \mathrm{~s}$ spectrum of ppT-air also showed an increase of moieties associated with $\mathrm{C}=\mathrm{O}$ and $\mathrm{O}-\mathrm{C}=\mathrm{O}$.

\section{STEM CELL MORPHOLOGY}

Our choice of Wharton's jelly-derived MSCs for this study was based on their wide availability plus their high proliferation and osteogenic formation relative to other MSCs such as bone marrow or adipose tissue MSCs; furthermore, other MSCs tend to require invasive 
extraction processes and exhibit reduced differentiation capacity with increasing age (Shen et al. 2019).

In our stem cell morphology study, Figure 1 shows the viability of undifferentiated WJ-MSCs on the samples, visualized via fluorescence staining of F-actin. Cells grown on the ppOD surface demonstrated weak and sparse adhesion in the form of clustered, almost spheroidal growth; notably, ppOD is akin to plasma-polymerized hexane, which primarily consists of $\mathrm{CH}_{3}$ moieties. These moieties provide good MSC infiltration for 3D scaffolds (Curran et al. 2013), but on flat self-assembled monolayer modified surfaces, like our plasma polymers, promote nonadhesion of MSCs (Liu et al. 2013). Other researchers have reported that substrates incorporating $\mathrm{CH}_{3}$ groups enhanced the stability of MSC phenotype (Curran et al. 2010a), even for osteogenic differentiation in a stimulated media condition (Curran et al. 2010b). In other study, human adipose stem cells on surfaces modified with $\mathrm{CH}_{3}$ moieties show the slowest growth rates; ranked in descending order, relative growth rates by surface are as follows: $\mathrm{NH}_{2}>\mathrm{SH}>\mathrm{COOH}>$ phenyl $>\mathrm{Br}>\mathrm{OH}>\mathrm{CH}_{3}$ ( $\mathrm{Liu}$ et al. 2013).
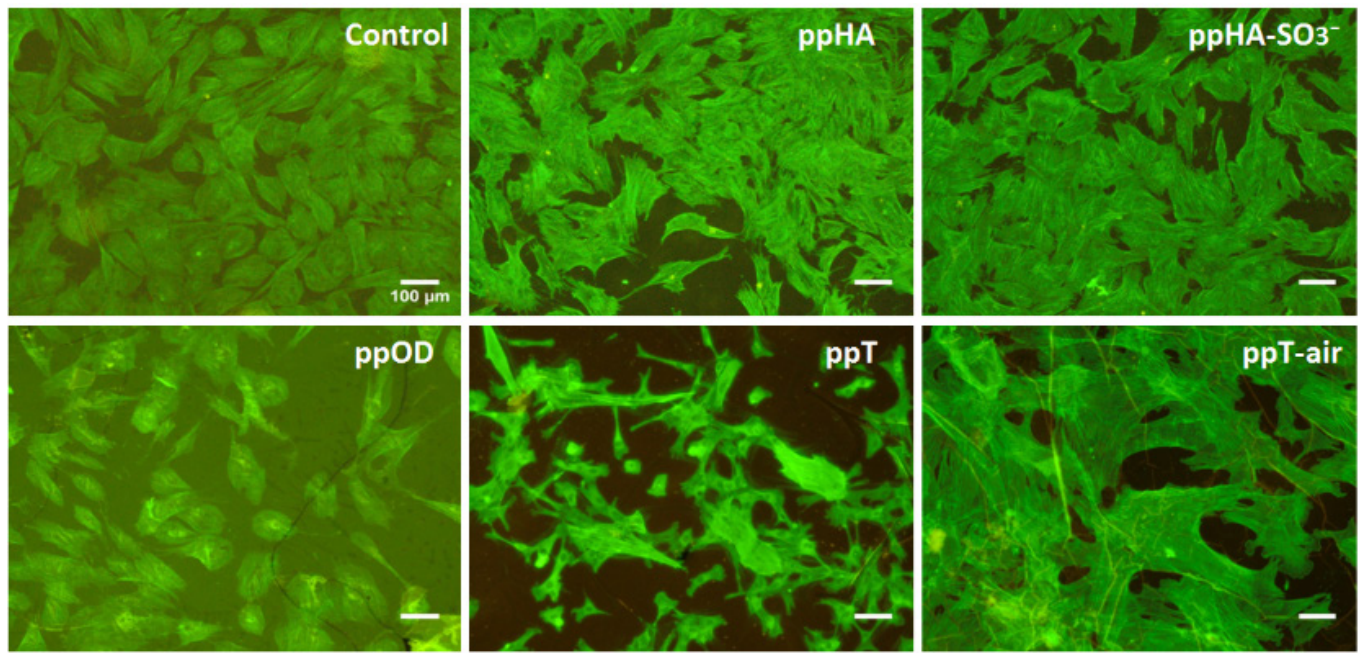

FIGURE 1. Cell morphology and viability of WJ-MSCs grown on different plasma-modified substrates as observed by fluorescence microscopy at day 14 ; scale bar $=100 \mu \mathrm{m}, \mathrm{n} \geq 3$

On the ppHA and ppHA-SO $\mathrm{S}_{3}$ substrates, WJ-MSCs displayed cytoskeletons that were well spread and homogeneously distributed, similar to those grown on a glass substrate (positive control). Cells grown on the $\mathrm{ppT}$ and ppT-air substrates were star-shaped with elongated actin stress fibres, similar to those of MSCs seeded on $\mathrm{SO}_{3}$-terminated SAMs and grown without serum over a short incubation period (24 h) (da Costa et al. 2012). On ppT-air in particular, the high oxidation state of $\mathrm{S}$ intensified the length of actin stress fibres. These observed morphologies, shown in Figure 1, agree with the MTT cell proliferation tests discussed next.
STEM CELL VIABILITY: MTT ASSAY

We used MTT for comparative cell viability testing because of its reliable measurement of cellular activity and proliferation (Röder et al. 2015). MTT results can be affected by metabolism rate, which depends on nutrients (e.g. glutamine availability), osmolarity and temperature (Fernandez-De-Cossio-DIaz \& Vazquez 2018; Wang et al. 2019). However, as F-actin staining showed an increased number of WJ-MSCs (Figure 1), the changes observed with the MTT assay (Figure 2) are more likely attributable to cellular proliferation rather than individual cellular metabolism per se. 


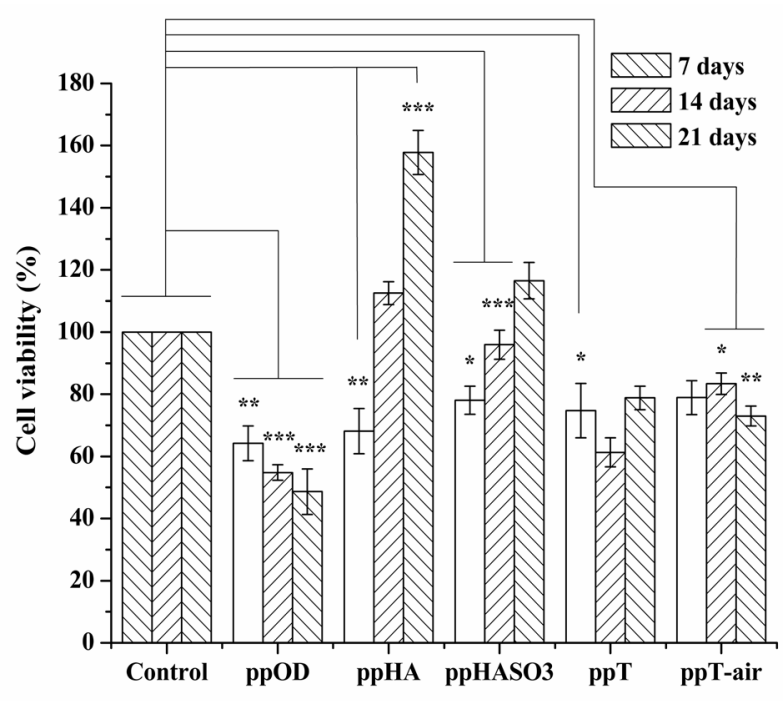

FIGURE 2. MTT assays were carried out at day 7, 14, and 21 for WJ-MSCs grown on different plasma-polymerized samples; data are expressed as mean \pm standard error (SEM), $n \geq 4$. Asterisks indicate statistically significant difference compared with controls of the same timepoint $(* p<0.05, * * p<0.01, * * * p<0.001)$

Here, WJ-MSCs grown on ppHA and ppHA-SO increases from day 7 to day 21, with ppHA increasing from approximately 65 to $156 \%$ and $\mathrm{ppHA}_{-} \mathrm{SO}_{3}$ increasing from 76 to $112 \%$ over that period. Consistent with these results, it has been reported elsewhere that a $\mathrm{NH}_{2}$-rich substrate assists the adhesion and proliferation of $\mathrm{WJ}$ MSCs (Xujie et al. 2014).

While ppT-air showed an improvement in cell adhesion relative to $\mathrm{ppT}$ at 14 days, no significant difference was observed with longer incubation, i.e. at 21 days. S-containing moieties with higher oxidation, e.g. $\mathrm{SO}_{3}$ or $\mathrm{SO}_{4}$, are generally conducive to cell adhesion, such as for human endothelial cells (Klee et al. 1994); however, these were likely not present in ppT-air at sufficient concentration to influence protein adsorption from the serum of the basal media. Additionally, reduction of mouse fibroblast cell adhesion has been reported with a high density of $\mathrm{SO}_{3}$ moieties (i.e. $3.5 \mu \mathrm{g} / \mathrm{cm}^{2}$ ) in a $48-\mathrm{h}$ incubation test; this suggests that in shorter incubations, adhesion depends on cell type and chemical moiety concentration (Ito et al. 1991). At the longer duration of 21 days used here, it is likely that the WJ-MSCs re-modelled the extracellular matrices to conceal the underlying chemical differences between ppT and ppT-air (García 2005).
The SH group has also been shown to have a positive influence on MSC proliferation; per Liu et al. (2013), the growth rate is between those of $\mathrm{NH}_{2}$ and $\mathrm{COOH}$ and significantly higher than that of $\mathrm{CH}_{3}$. Over the first 7 days of incubation, our study did not show any significant differences in growth rate between $\mathrm{CH}_{3}$ (from ppOD) and $\mathrm{SH}$ (from ppT), but at 21 days, the beneficial effect of SH moieties were evident in the improved viability of WJ-MSCs on ppT compared to ppOD, although they remained less viable than cells grown on a glass substrate (positive control). Furthermore, ppOD was the only surface to demonstrate a reduction of WJ-MSC viability between days 7 and 21 .

While it is tempting to attribute this impaired cell viability to the hydrophobicity of the ppOD-modified surface, various studies have demonstrated that such cellular interactions are mainly moderated by the overall surface chemistry (Liu et al. 2014; Phillips et al. 2010; Siow 2018; Siow et al. 2015). In particular, $\mathrm{COOH}-$ modified surfaces demonstrate less MSC attachment and osteogenesis than those modified with $\mathrm{NH}_{2}$ functionalities, despite $\mathrm{COOH}$ being the more hydrophilic surface (Liu et al. 2014).

Furthermore, surfaces with $\mathrm{NH}_{2}$ groups and $\mathrm{COOH}$ groups, can have opposite charges namely positive and 
negative charges respectively, which markedly affects protein adsorption from complex media such as body fluids to which proteins adsorb, and how much they denature which will then affect cell attachment. But more important is that the adhesion of cells, per se, does not convey the full message - it is more important what happens after MSCs attach i.e. which metabolic activity is activated. This interest motivated our subsequent osteogenic differentiation tests with qPCR, alizarin red $\mathrm{S}$ and ALP assay.

\section{OSTEOGENIC DIFFERENTIATION: QPCR}

To evaluate the capacity of WJ-MSCs to differentiate into osteoblast phenotypes on various plasma polymers coatings, WJ-MSCs were induced with osteogenic differentiation medium for 21 days. In this study, the growth and differentiation of the induced osteoblast lineage cells were evaluated through osteogenic gene expression analysis, osteogenic enzyme activity measurement, and mineralization quantification. For gene expression analysis, two osteogenic genes, namely Runt-related transcription factor 2 (RUNX2) and osteopontin (OPN), were used to evaluate the proliferation stage of osteoblast lineage cells. RUNX2 is the most crucial transcription factor and indicates early-stage osteogenic differentiation; specifically, it promotes the differentiation of MSCs into osteoblast lineages by activating osteogenic differentiation-related genes, including fibronectin, type 1 collagen, OPN, bone sialoprotein, osteorix, ALP, and osteocalcin (Bruderer et al. 2014; Kirkham \& Cartmell 2007; Xu et al. 2015).

Exposure of WJ-MSCs to osteogenic differentiation medium resulted in high expression of RUNX2 relative to those cultured in basal growth media without the osteogenic-promoting additives (Figure 3; glass control: 10.458, ppOD: 9.159, ppHA: 7.157, ppHA-SO $_{3}$ : 7.201, ppT: 8.942, ppT-air: 6.518), thus confirming initiation of WJ-MSC differentiation into the osteoblast lineage.

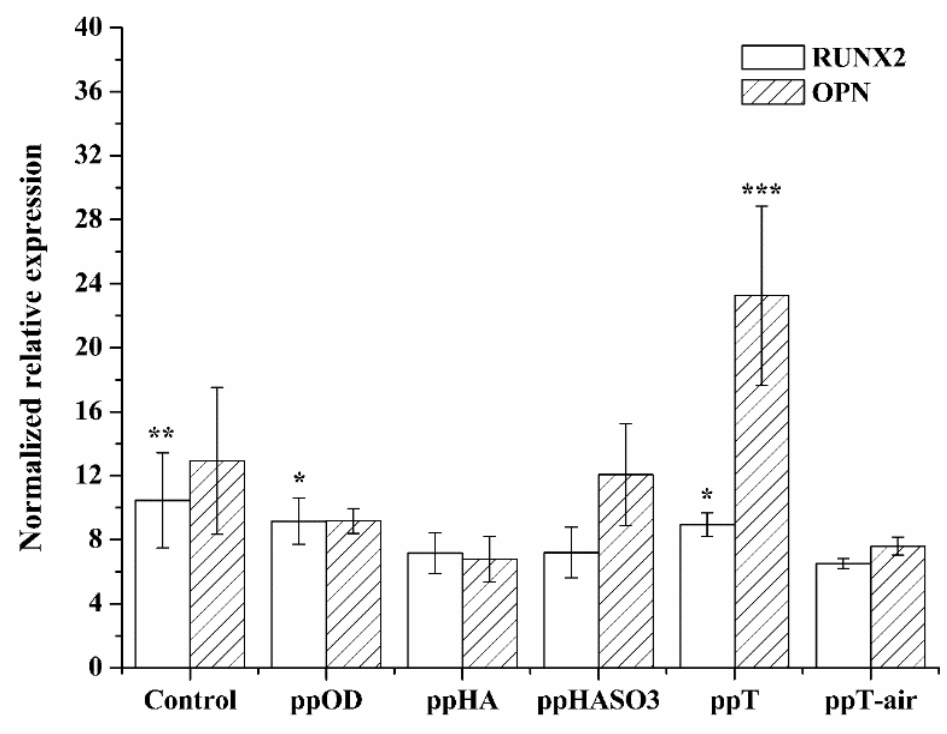

FIGURE 3. Assessment by qPCR of osteogenic gene expression at day 21 after induction of WJ-MSCs grown on different plasma-modified samples or glass coverslip (control). Data are presented as expression levels of RUNX2 and OPN of induced WJ-MSCs relative to control cells cultured in basal growth medium without the osteogenic-promoting additives (undifferentiated), and were normalised against the reference gene $\beta$-actin. Data are expressed as mean \pm SEM, $\mathrm{n}=3$. $^{*} p<0.05$, $* * p<$ $0.01, * * * p<0.001$ compared to undifferentiated WJ-MSCs

OPN, also known as secreted phosphoprotein 1 (SPP1), is a secreted adhesive glycophosphoprotein expressed in most body tissues and fluids, including bone matrix (Kirkham \& Cartmell 2007). OPN is highly expressed during the early stage of osteoblast development to support cell cycle progression and proliferation. The subsequent transition stage is marked by the down-regulation of proliferation-linked genes as cells exit from the cell cycle and initiate their differentiation into mature osteoblasts. During this 
transition, ALP activity and the expression of extracellular matrix-related proteins are elevated to respectively promote the maturation and subsequent mineralization of the bone extracellular matrix (Rutkovskiy et al. 2016; Smane \& Pilmane 2016; Stein et al. 2004). A reduction in OPN expression after some time indicates progression of the osteoblasts from proliferation to differentiation stages.

In this study, cells cultured on ppHA expressed less OPN at day 21 than did those grown on other surfaces, suggesting that of the tested surfaces, ppHA promotes the most rapid proliferation and differentiation of osteoblasts. Meanwhile, cells grown on the ppT surface displayed the highest level of OPN expression on day 21, indicating that these cells remained in the proliferation phase and required much more time to differentiate into mature osteoblasts. This demonstrates the limited capability of substrates containing high concentrations of $\mathrm{S}$ moieties to promote osteogenic differentiation.

\section{OSTEOGENIC DIFFERENTIATION: ALIZARIN RED S AND ALKALINE PHOSPHATASE ASSAY}

Figure 4 shows the morphological analysis of alizarin red S-stained osteoblasts after 21 days, while Figure 5 illustrates ALP activity after 7, 14, and 21 days. The ability of alizarin red $\mathrm{S}$ to selectively bind calcium salts serves as a useful marker for imaging the mineralization stage of osteogenic differentiation, while ALP activity serves as a marker of extracellular matrix maturation; their combined presence shows the suitability of a given plasma-modified substrate to support differentiation of WJ-MSCs into osteoblasts.
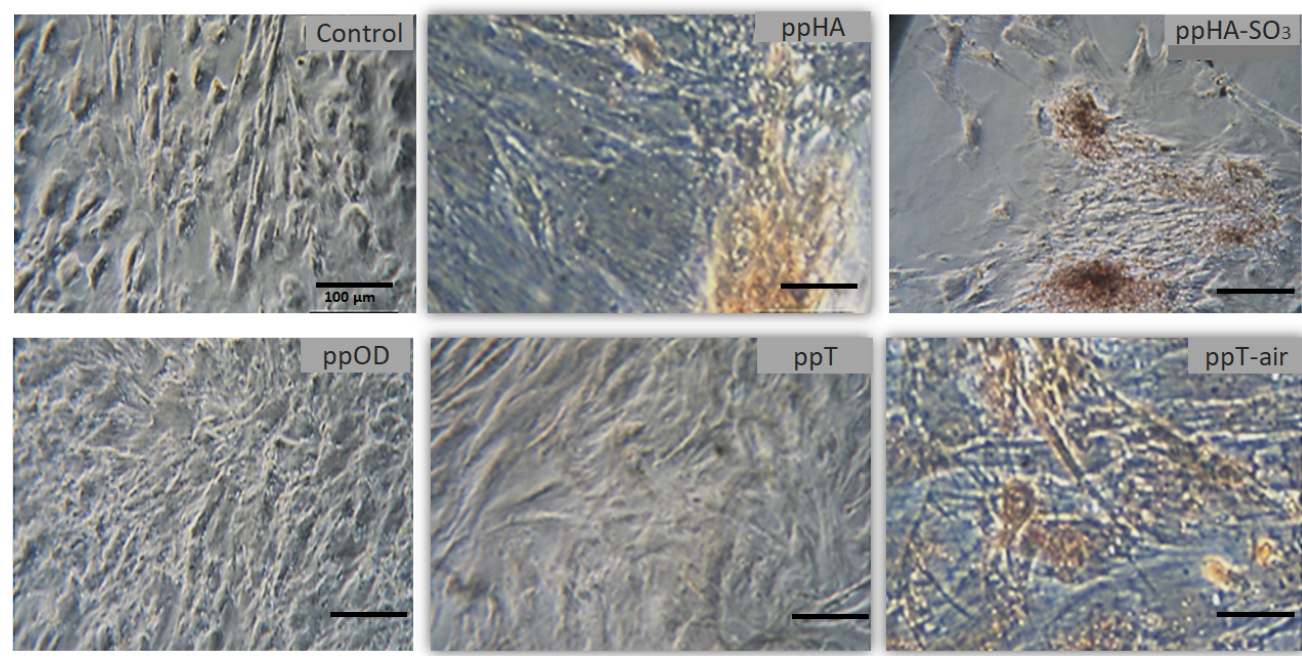

FIGURE 4. Mineral deposition and osteoblast formation for osteogenically differentiated WJ-MSCs grown on different substrates for 21 days. Cells were stained with alizarin red S (red precipitation) and the images captured under an inverted microscope

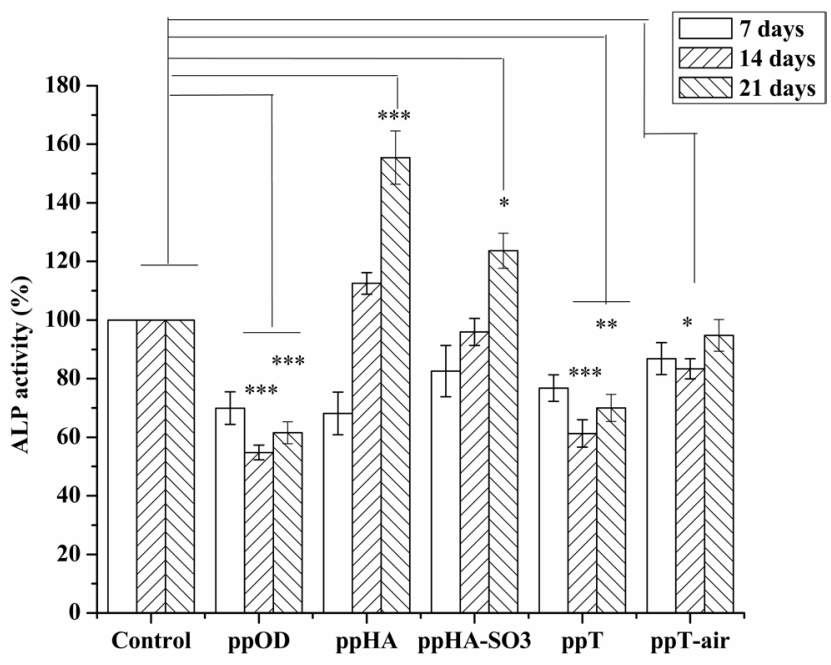

FIGURE 5. Osteoblast production measured using ALP assay on days 7, 14, and 21; data expressed as mean \pm standard error (SEM), $\mathrm{n} \geq 3$. Statistically significant findings at $* p<0.05, * * p<0.01, * * * p<0.001$ (for days 14 and

$21)$ are relative to respective controls at the same incubation timepoint 
As mentioned earlier, the ability of WJ-MSCs to form mature fibrillar adhesions depends on the MSC type, stimulating medium, and the physical/chemical properties of the substrate. All plasma polymers had surface root mean square roughness of less $30 \mathrm{~nm}$, based on atomic force microscopy measurement, which was deemed to not influence the cells. The character of cell adhesion to the substrate influences the cytoskeleton to direct the cellular gene expression profile to be more or less osteogenic. Here, positive effects of amines/amides from ppHA and ppHA- $\mathrm{SO}_{3}$ on the osteogenic activity of WJ-MSCs were readily evident (Figure 4); these plasma polymers coatings displayed visible mineralization. This finding confirmed the implication of the gene expression analysis concerning the transition of WJ-MSCs into osteoblasts on these coatings.

The most common explanation for this observation is that osteoblast differentiation is mediated by the influence of $\mathrm{NH}_{2}$ moieties on adsorbed fibronectin proteins and resulting binding of integrin $\alpha_{5} \beta_{1}$ (Moursi et al. 1997). A positive role for $\mathrm{NH}_{2}$ has also been reported by others (Curran et al. 2013; Liu et al. 2013). In separate research, comparable improvements in stem cell attachment have been observed with $\mathrm{NH}_{2}, \mathrm{OH}$, and $\mathrm{COOH}$ chemical groups, but the highest level of osteogenic differentiation was obtained with $\mathrm{NH}_{2}$, based on ALP activity and mineralization level as determined by alizarin red staining (Liu et al. 2014). Meanwhile, $\mathrm{OH}$ was found to promote chondrogenic differentiation by minimizing focal contact formation while still maintaining viable cell adhesion (Curran et al. 2013). Similar results in terms of preferential chondrogenic differentiation by MSCs have also been reported for surfaces modified with $\mathrm{COOH}$ and $\mathrm{OH}$ moieties, regardless of the presence of biological stimuli in cell media (Curran et al. 2006).

Part of the ALP results has been published previously (Siow et al. 2020), and is included here in Figure 5 for readers' convenience. No samples demonstrated any significant ALP activity on day $7(p>0.05)$ because WJ-MSCs have a long osteogenesis process, even in the presence of osteogenic media. However, significant increases in ALP activity were observed from day 14 to day $21(p<0.05)$. Specifically, ALP activity of ppHA increased by $155 \%$ and ppHA-SO $\mathrm{SO}_{3}$ by $124 \%$, indicating that the presence of $\mathrm{SO}_{3}$ reduced ALP activity associated with the osteogenic process. This result mirrored the visible reduction of WJ-MSC proliferation on ppHA-SO (Figure 2).

Meanwhile, cells grown on ppT-air (which incorporates $\mathrm{SO}_{4}$ ) displayed only 95\% ALP activity at day 21 . While the positive influence of $\mathrm{NH}_{2}$ from ppHA or other SAM has been well documented, the roles of $\mathrm{SO}_{3}$ (ppHA-SO ${ }_{3}$ ) and $\mathrm{SO}_{4}$ (ppT-air) have not been thoroughly elucidated. $\mathrm{SO}_{3}$ has been shown to influence filopodia formation by MSCs during a short-term cell proliferation incubation of $24 \mathrm{~h}$ (da Costa et al. 2012), but its electronegative charges might reduce the efficacy of the positively charged amine of ppHA in producing the high $\mathrm{pH}$ values conducive to osteogenesis. That osteogenesis and osteoblast proliferation is enhanced in environments with a $\mathrm{pH}$ of more than 8 has been demonstrated elsewhere (Shen et al. 2011). To the best of our knowledge, the mechanism underlying the negative effects observed with $\mathrm{SO}_{4}$, which has no charge, has yet to be explained.

Cells grown on ppT and ppOD coatings registered ALP activities of only 70 and $62 \%$, respectively, which suggests severe limitation of the osteogenesis process by these substrates. While an adverse effect of the $\mathrm{CH}_{3}$ moieties of ppOD has been demonstrated above, the lack of osteogenic activities evidenced here by loweroxidation $\mathrm{S}$ moieties like $\mathrm{SH}$ (from $\mathrm{ppT}$ ) is somewhat revealing. Only one other research reported that $\mathrm{SH}$ groups promote chondrogenicity, albeit with different stem cells (i.e. human adipose stem cells) and tests (i.e. up-regulation of type II collagen and aggrecan) (Liu et al. 2013). Overall, the findings of these osteogenic differentiation analyses (i.e. gene expression analysis, ALP activity, and alizarin red S staining) provide corroborating evidence of the various plasma-modified surfaces to influence the differentiation capacity of WJ-MSCs.

\section{CONCLUSION}

In conclusion, we successfully tested the ability of plasma-modified substrates containing $\mathrm{S}$ and $\mathrm{N}$ in varying percentages and oxidation states to influence osteoblast cell viability and differentiation. The S-related plasma modification approaches consisted of plasma polymerization of n-heptylamine with grafting of vinyl- $\mathrm{SO}_{3}$ via Michaeltype addition ( $\mathrm{ppHA}-\mathrm{SO}_{3}$ ), plasma polymerization of thiophene (ppT), and ppT with subsequent air plasma treatment (ppT-air). The presence of $\mathrm{SO}_{3}$ moieties reduced proliferation and differentiation of WJ-MSCs relative to those incubated on the $\mathrm{NH}_{2}$-dominated ppHA. However, the higher oxidation $\mathrm{S}$ (i.e. $\mathrm{SO}_{4}$ ) of the ppT-air substrate positively influenced WJ-MSCs differentiation relative to the original ppT-coated substrate. In addition, our qPCR results also suggested that OPN expression could provide a preliminary insight into the efficiency of these plasma polymers in promoting osteogenesis, which could not be verified by RUNX2 expression in this current study design. While we are confident that these current results can be replicated with other MSCs, based on findings from similar plasma-polymerized substrates with human adipose derived-MSCs (Liu et al. 2015, 2014, 2013) or human bone marrow-derived MSCs (Curran et al. 2006; Sandstrom et al. 2013), confirming this will be the focus of our subsequent work with a new qPCR study design. 


\section{ACKNOWLEDGEMENTS}

We acknowledged the financial support from the Ministry of Education, Malaysia (AKU254: IMEN HICOE Phase II) for this work.

\section{REFERENCES}

Akhavan, B., Jarvis, K. \& Majewski, P. 2014. Development of oxidized sulfur polymer films through a combination of plasma polymerization and oxidative plasma treatment. Langmuir 30(5): 1444-1454.

Beamson, G. \& Briggs, D. 1992. High resolution XPS of organic polymers. Journal of Chemical Education 70(1): A25.

Beck, A.J., Whittle, J.D., Bullett, N.A., Eves, P., Mac Neil, S., McArthur, S.L. \& Shard, A.G. 2005. Plasma copolymerisation of two strongly interacting monomers: Acrylic acid and allylamine. Plasma Processes and Polymers 2(8): 641-649.

Bruderer, M., Richards, R.G., Alini, M. \& Stoddart, M.J. 2014. Role and regulation of RUNX2 in osteogenesis. European Cells and Materials 28: 269-286.

Chan, Y.W., Siow, K.S., Ng, P.Y., Gires, U. \& Majlis, B.Y. 2016. Plasma polymerized carvone as an antibacterial and biocompatible coating. Materials Science and Engineering: C 68: 861-871.

Chen, T.F., Siow, K.S., Ng, P.Y., Nai, M.H., Lim, C.T. \& Yeop Majlis, B. 2016. Ageing properties of polyurethane methacrylate and off-stoichiometry thiol-ene polymers after nitrogen and argon plasma treatment. Journal of Applied Polymer Science 133(42):133.

da Costa, D.S., Pires, R.A., Frias, A.M., Reis, R.L. \& Pashkuleva, I. 2012. Sulfonic groups induce formation of filopodia in mesenchymal stem cells. Journal of Materials Chemistry 22(15): 7172-7178.

Curran, J.M., Fawcett, S., Hamilton, L., Rhodes, N.P., Rahman, C.V., Alexander, M., Shakesheff, K. \& Hunt, J.A. 2013. The osteogenic response of mesenchymal stem cells to an injectable PLGA bone regeneration system. Biomaterials 34(37): 9352-9364.

Curran, J.M., Chen, R. \& Hunt, J.A 2010a. Material induced mesenchymal stem cell differentiation. Biomaterials 31(6): 1463-1464.

Curran, J.M., Stokes, R., Irvine, E., Graham, D., Amro, N.A., Sanedrin, R.G., Jamil, H. \& Hunt, J.A. 2010b. Introducing dip pen nanolithography as a tool for controlling stem cell behaviour: Unlocking the potential of the next generation of smart materials in regenerative medicine. Lab on a Chip 10(13): 1662-1670.

Curran, J.M., Chen, R. \& Hunt, J.A. 2006. The guidance of human mesenchymal stem cell differentiation in vitro by controlled modifications to the cell substrate. Biomaterials 27(27): 4783-4793.

Fernandez-De-Cossio-DIaz, J. \& Vazquez, A. 2018. A physical model of cell metabolism. Scientific Reports 8(1): 8349.

García, A.J. 2005. Get a grip: Integrins in cell-biomaterial interactions. Biomaterials 26(36): 7525-7529.

Ito, Y., Iguchi, Y., Kashiwagi, T. \& Imanishi, Y. 1991. Synthesis and nonthrombogenicity of polyetherurethaneurea film grafted with poly(sodium vinyl sulfonate). Journal of Biomedical Materials Research 25(11): 1347-1361.

Keselowsky, B.G., Collard, D.M. \& García, A.J. 2003. Surface chemistry modulates fibronectin conformation and directs integrin binding and specificity to control cell adhesion. Journal of Biomedical Materials Research - Part A 66(2): 247-259.

Keshel, S.H., Azhdadi, S.N.K., Asefnezhad, A., Sadraeian, M., Montazeri, M. \& Biazar, E. 2011. The relationship between cellular adhesion and surface roughness for polyurethane modified by microwave plasma radiation. International Journal of Nanomedicine 6: 641-647.

Kirkham, G.R. \& Cartmell, S.H. 2007. Genes and proteins involved in the regulation of osteogenesis. Genes and Osteogenesis 3: 1-22.

Klee, D., Villari, R.V., Höcker, H., Dekker, B. \& Mittermayer, C. 1994. Surface modification of a new flexible polymer with improved cell adhesion. Journal of Materials Science: Materials in Medicine 5(9-10): 592-595.

Liu, X., He, J., Zhang, S., Wang, X.M., Liu, H.Y. \& Cui, F.Z. 2013. Adipose stem cells controlled by surface chemistry. Journal of Tissue Engineering and Regenerative Medicine 7(2): 112-117.

Liu, X., Feng, Q., Bachhuka, A. \& Vasilev, K. 2014. Surface modification by allylamine plasma polymerization promotes osteogenic differentiation of human adipose-derived stem cells. ACS Applied Materials and Interfaces 6(12): 9733 9741.

Liu, X., Shi, S., Feng, Q., Bachhuka, A., He, W., Huang, Q. Zhang, R., Yang, X. \& Vasilev, K. 2015. Surface chemical gradient affects the differentiation of human adipose-derived stem cells via ERK1/2 signaling pathway. ACS Applied Materials and Interfaces 7(33): 18473-18482.

Mager, M.D., LaPointe, V. \& Stevens, M.M. 2011. Exploring and exploiting chemistry at the cell surface. Nature Chemistry 3(8): 582-589.

Manton, K.J., Leong, D.F., Cool, S.M. \& Nurcombe, V. 2007. Disruption of heparan and chondroitin sulfate signaling enhances mesenchymal stem cell-derived osteogenic differentiation via bone morphogenetic protein signaling pathways. Stem Cells 25(11): 2845-2854.

Moursi, A.M., Globus, R.K. \& Damsky, C.H. 1997. Interactions between integrin receptors and fibronectin are required for calvarial osteoblast differentiation in vitro. Journal of Cell Science 110(18): 2187-2196.

Phillips, J.E., Petrie, T.A., Creighton, F.P. \& García, A.J. 2010. Human mesenchymal stem cell differentiation on self-assembled monolayers presenting different surface chemistries. Acta Biomaterialia 6(1): 12-20.

Röder, A., García-Gareta, E., Theodoropoulos, C., Ristovski, N., Blackwood, K.A. \& Woodruff, M.A. 2015. An assessment of cell culture plate surface chemistry for in vitro studies of tissue engineering scaffolds. Journal of Functional Biomaterials 6(4): 1054-1063.

Rutkovskiy, A., Stensløkken, K.O. \& Vaage, I.J. 2016. Osteoblast differentiation at a glance. Medical Science Monitor Basic Research 22: 95-106.

Sandstrom, A.M., Jasieniak, M., Griesser, H.J., Grøndahl, L. \& Cooper-White, J.J. 2013. Effects of varying heptylamine 
and propionaldehyde plasma polymerization parameters on mesenchymal stem cell attachment. Plasma Processes and Polymers 10(1): 19-28.

Scotchford, C.A., Gilmore, C.P., Cooper, E., Leggett, G.J. \& Downes, S. 2002. Protein adsorption and human osteoblastlike cell attachment and growth on alkylthiol on gold selfassembled monolayers. Journal of Biomedical Materials Research 59(1): 84-99.

Shen, C., Yang, C., Xu, S. \& Zhao, H. 2019. Comparison of osteogenic differentiation capacity in mesenchymal stem cells derived from human amniotic membrane (AM), umbilical cord (UC), chorionic membrane (CM), and decidua (DC). Cell and Bioscience 9(1): 17.

Shen, Y., Liu, W., Lin, K., Pan, H., Darvell, B.W., Peng, S., Wen, C., Deng, L., Lu, W.W. \& Chang, J. 2011. Interfacial pH: A critical factor for osteoporotic bone regeneration. Langmuir 27(6): 2701-2708.

Silver, J.H., Lin, J.C., Lim, F., Tegoulia, V.A., Chaudhury, M.K. \& Cooper, S.L. 1999. Surface properties and hemocompatibility of alkyl-siloxane monolayers supported on silicone rubber: Effect of alkyl chain length and ionic functionality. Biomaterials 20(17): 1533-1543.

Siow, K.S. 2018. Low pressure plasma modifications for the generation of hydrophobic coatings for biomaterials applications. Plasma Processes and Polymers 15(9): 1800059.

Siow, K.S., Rahman, A.S.A., Ng, P.Y. \& Majlis, B.Y. 2020. Sulfur and nitrogen containing plasma polymers reduces bacterial attachment and growth. Materials Science and Engineering C 107: 110225 .

Siow, K.S., Britcher, L., Kumar, S. \& Griesser, H.J. 2019. QCM-D and XPS study of protein adsorption on plasma polymers with sulfonate and phosphonate surface groups. Colloids and Surfaces B: Biointerfaces 173: 447-453.

Siow, K.S., Britcher, L., Kumar, S. \& Griesser, H.J. 2018. XPS study of sulfur and phosphorus compounds with different oxidation states. Sains Malaysiana 47(8): 1913-1922.

Siow, K.S., Britcher, L., Kumar, S. \& Griesser, H.J. 2017. Plasma polymers containing sulfur and their co-polymers with 1,7-octadiene: Chemical and structural analysis. Plasma Processes and Polymers 14(3): 1600044

Siow, K.S., Kumar, S. \& Griesser, H.J. 2015. Low-pressure plasma methods for generating non-reactive hydrophilic and hydrogel-like bio-interface coatings - A review. Plasma Processes and Polymers 12(1): 8-24.

Siow, K.S., Britcher, L., Kumar, S. \& Griesser, H.J. 2014 Deposition and XPS and FTIR analysis of plasma polymer coatings containing phosphorus. Plasma Processes and Polymers 11(2): 133-141.

Smane, L. \& Pilmane, M. 2016. Osteopontin, osteocalcin, and osteoprotegerin expression in human tissue affected by cleft lip and palate. SHS Web of Conferences 30: 00008.

Stein, G.S., Lian, J.B., Van Wijnen, A.J., Stein, J.L., Montecino, M., Javed, A., Zaidi, S.K., Young, D.W., Choi, J.Y. \& Pockwinse, S.M. 2004. Runx2 control of organization, assembly and activity of the regulatory machinery for skeletal gene expression. Oncogene 23(24): 4315-4329.

Uygun, B.E., Stojsih, S.E. \& Matthew, H.W. 2009. Effects of immobilized glycosaminoglycans on the proliferation and differentiation of mesenchymal stem cells. Tissue Engineering - Part A 15(11): 3499-3512.

Wang, Y., Bai, C., Ruan, Y., Liu, M., Chu, Q., Qiu, L., Yang, C. \& Li, B. 2019. Coordinative metabolism of glutamine carbon and nitrogen in proliferating cancer cells under hypoxia. Nature Communications 10(1): 201.

Wells, N., Baxter, M.A., Turnbull, J.E., Murray, P., Edgar, D., Parry, K.L., Steele, D.A. \& Short, R.D. 2009. The geometric control of E14 and R1 mouse embryonic stem cell pluripotency by plasma polymer surface chemical gradients. Biomaterials 30(6): 1066-1070.

Xu, J.H., Li, Z.H., Hou, Y.D. \& Fang, W.J. 2015. Potential mechanisms underlying the runx2 induced osteogenesis of bone marrow mesenchymal stem cells. American Journal of Translational Research 7(12): 2527-2535.

Kim Shyong Siow* \& Arifah Rahman Institute of Microengineering and Nanoelectronics

Universiti Kebangsaan Malaysia 43600 UKM Bangi, Selangor Darul Ehsan

Malaysia

Amnani Aminuddin \& Pei Yuen Ng

Drug and Herbal Research Centre

Faculty of Pharmacy

Universiti Kebangsaan Malaysia

50300 Kuala Lumpur, Federal Territory

Malaysia

*Corresponding author; email: kimsiow@ukm.edu.my

Received: 11 April 2020

Accepted: 14 June 2020 

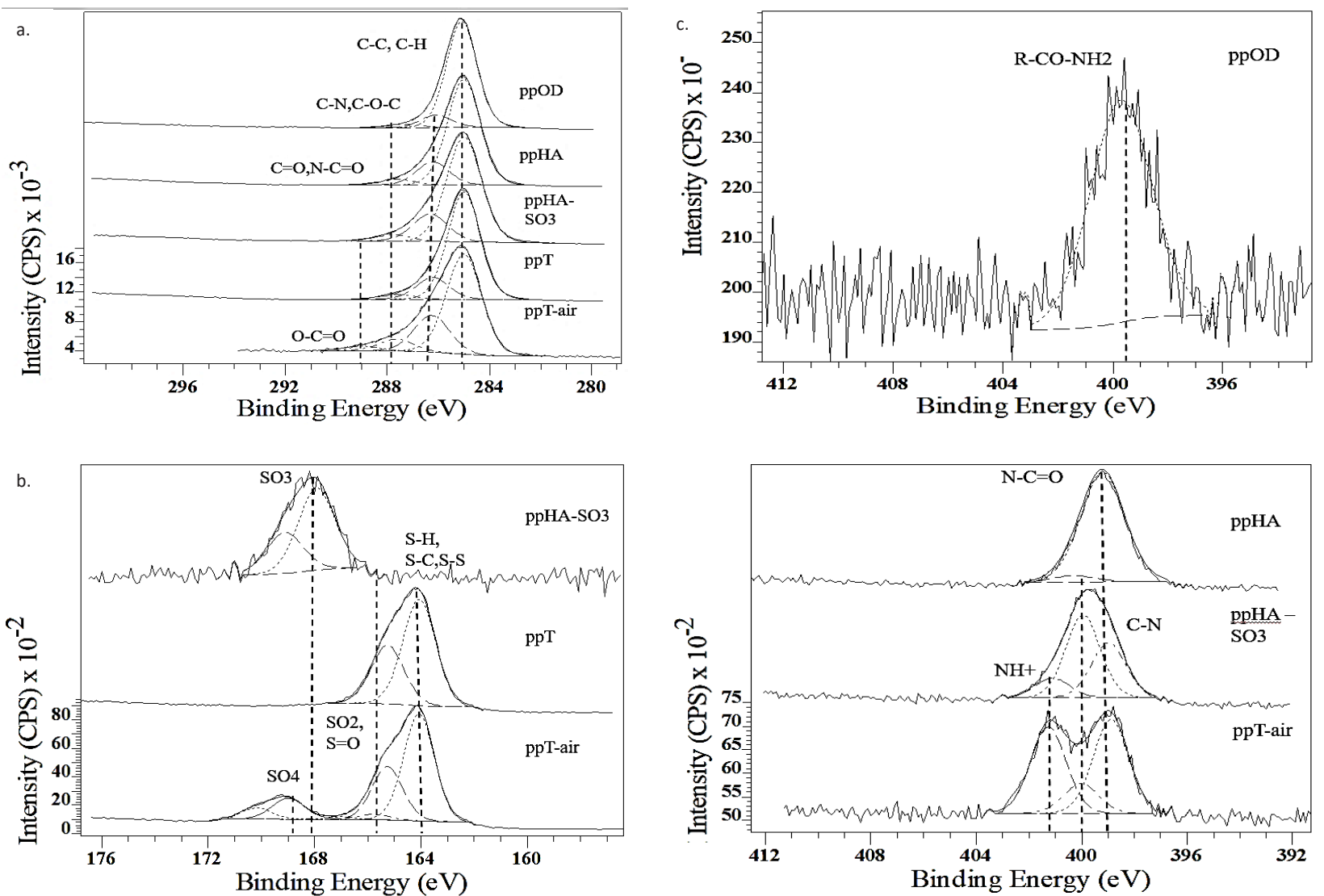

SUPPLEMENTARY S1. XPS component-fitted (a) C1s, (b) S2p, and (c) N1s spectra for representative ppOD, ppHA, ppHA-SO ${ }_{3}$ ppT and ppT-air coatings 